\title{
The comparison of temporal temperature measurement method by non-contact infrared thermometer with other body temperature measurement methods
}

\section{Temassız kızılötesi termometre aracılığıyla temporal sıcaklık ölçüm yönteminin diğer vücut sıcaklık ölçüm yöntemleriyle karşılaştırılması}

\author{
Nilay HAKAN ${ }^{1}$, Nurullah OKUMUŞ ${ }^{2}$, Mustafa AYDIN ${ }^{3}$, Tuncay KÜÇÜKÖZKAN ${ }^{4}$, Nilden TUYGUN ${ }^{5}$, \\ Ayşegül ZENCİROĞLU ${ }^{6}$
}

${ }^{1}$ Muğla Sitkı Koçman Üniversitesi Tip Fakültesi, Neonatoloji Bilim Dalı, Muğla

${ }^{2}$ Yıldırım Beyazıd Üniversitesi Tip Fakültesi, Neonatoloji Bilim Dalı, Ankara

${ }^{3}$ Firat Üniversitesi Tip Fakültesi, Neonatoloji Bilim Dalı, Elazı $\breve{g}$

${ }^{4}$ S.B. Sağlık Bilimleri Üniversitesi Dr. Sami Ulus Kadın Doğum, Çocuk Sağlı̆̆ı ve Hastalıkları Ĕ̆gitim ve Araştırma Hastanesi, Kadın Hastalıkları ve Doğum Klini ği, Ankara

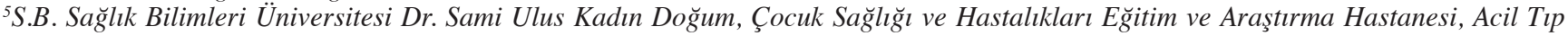
Kliniği, Ankara

${ }^{6}$ S.B. Să̆lık Bilimleri Üniversitesi Dr. Sami Ulus Kadın Doğum, Çocuk Să̆lı̆̆ v ve Hastalıkları Ĕ̆itim ve Araştırma Hastanesi, Yenidoğan Kliniği, Ankara

\section{ABSTRACT}

\begin{abstract}
Objective: To evaluate the effectiveness of non-contact infrared thermometer (NCIT) by comparing with other thermometers and/or body temperature measurement methods.

Methods: The patients were divided into 3 groups: $0-1$ year-old babies, $>16$ year-old female patients, and 1-16 year-old children. The body temperature of all patients was measured by NCIT at the temporal region, and the digital thermometer through the axillary region. Moreover, body temperature of the children was measured with tympanic thermometer and of adults with digital thermometer through oral route.

Results: When compared to other temperature measurement methods, in all patients, the temporal temperature was not statistically different to that of rectal temperature $(p>0.05)$; but it was $0.6^{\circ} \mathrm{C}$ higher than axillary $(\mathrm{p}<0.001), 0.3^{\circ} \mathrm{C}$ higher than oral $(\mathrm{p}<0.001)$, and $0.1^{\circ} \mathrm{C}$ higher than tympanic temperatures $(\mathrm{p}<0.001)$. If the rectal temperature of $\geq 38^{\circ} \mathrm{C}$ has been taken as a reference value for fever; the sensitivity, specificity, positive and negative predictive values for average temporal temperature were $48.5,99.5,88.9$, and $96.3 \%$, respectively. Based on visual inspection of the Bland-Altman plots, NCIT underestimated the higher body temperatures which resulted in a low sensitivity.

Conclusion: Our findings indicate that NCITs can be used as a rapid, hygienic and noninvasive method for excluding fever in children. However, this method has low sensitivity for detecting fever compared to that of rectal measurement and other noninvasive techniques. Although temporal temperature seems to be close to rectal temperature, this method is not ideal for detecting febrile patients yet.
\end{abstract}

Keywords: Fever, body temperature measurement, non-contact infrared thermometer, children

\section{$\ddot{\mathbf{O Z}}$}

Amaç: Temassız kızıl ötesi termometrenin (TKÖT) diğer termometreler ve/veya vücut sıcaklı̆̆ı ölçüm yöntemleri ile karşılaştırılması suretiyle etkinliğinin değerlendirilmesi amaçlandı.

Yöntem: Hastalar 0-1 yas arasındaki bebekler, >16 yas kadınlar ve 1-16 yas arasındaki cocuklar olmak üzere 3 gruba ayrıldı. Tüm hastaların vücut sıcaklığı, TKÖT aracılığıyla sağ ve sol temporal bölgelerden ve dijital termometre ile aksiller bölgeden ölçülmüştür. Ayrıca vücut sıcaklıkları tüm çocuklarda timpanik termometreyle ve yetişkinlerde ise oral yoldan dijital termometre ile ölçülmüştür.

Bulgular: Diğer sıcaklık ölçüm yöntemlerine kıyasla, tüm hastalarda temporal sıcaklık rektal sıcaklıktan farklı değildi $(p>0,05)$; aksiller sıcaklıktan $0,6^{\circ} \mathrm{C}$ daha yüksek $(p<0,001)$, oral sicaklıktan $0.3^{\circ} \mathrm{C}$ daha yüksek $(p<0,001)$ ve timpanik sıcaklıktan ise $0,1^{\circ} \mathrm{C}$ daha yüksekti $(p<0,001)$. Ĕğer ateş için $\geq 38^{\circ} \mathrm{C}$ rektal sıcaklık bir referans değer olarak alınırsa, ortalama temporal sıcaklık için duyarlılı,, özgüllü̈k, pozitif ve negatif prediktif değerler sırasıyla \%48,5,\%99,5, \%88,9 ve \%96,3 idi. Bland-Altman alanlarının görsel incelemesine göre, TKÖT yüksek vücut sıcaklığında sıcaklı̆̆ı olduğundan daha düşük tahmin etmekte ve bu nedenle düşük duyarlı̣ık göstermektedir.

Sonuç: Bulgularımız TKÖ̈T'lerin çocuklarda ateşi dışlamak için hızlı, hijyenik ve invaziv olmayan bir yöntem olarak kullanılabileceğini göstermektedir. Bununla birlikte, bu yöntem rektal ölcüm ve diğer invaziv olmayan tekniklerle karşlaştırıldığında, ateş saptamada düşük duyarlılığa sahiptir. Temporal sıcaklık rektal sıcaklığa yakın gibi görünse de, bu yöntem febril hastaların saptanması için henüz ideal değildir.

Anahtar kelimeler: Ateş, vücut sıcaklık ölçümü, temassız kızılötesi termometre, çocuklar
Alındı̆̆ı tarih: 05.06.2017

Kabul tarihi: 13.06 .2017

Yazışma adresi: Yrd. Doç. Dr. Nilay Hakan, Muğla Sıtkı Koçman Üniversitesi Tıp Fakültesi, Neonatoloji Bilim Dalı, Muğla e-mail:nhakan@hotmail.com 


\section{INTRODUCTION}

The body temperature measurement in children and adults is usually aimed to detect the fever. However, in newborn infants, it is applied to identify whether the baby is able to protect its own body temperature $^{(1)}$. It is very important to measure the body temperature accurately as it can be a symptom of a serious disease ${ }^{(2,3)}$. The most accurate and appropriate method for the measurement of body temperature has been investigated for many years. Various methods have been used to measure the body temperature. In practice, the body temperature is most commonly measured from the axillary, rectal, oral, or tympanic regions ${ }^{(4)}$. It is difficult to measure the body temperature of the children who are restless and cannot cooperate ${ }^{(5)}$. Nowadays, the body temperature is mainly measured by liquid crystal, chemical, and electronic thermometers. The common feature of these thermometers is the obligation to contact with the body parts, such as skin or mucous membranes. In recent years, the non-contact infrared thermometers (NCITs) have been developed to measure the body temperature through the radiation energy emitted from the object which is proportional to object's temperature. The major advantages of these infrared thermal devices are providing the opportunity for fast measurement and being noninvasive method for detecting the fever, and do not carry the risk of transmitting infection ${ }^{(6,7)}$.

The purpose of this study was to evaluate the effectiveness of NCITs by comparing other thermometers and/or body temperature measurement methods.

\section{MATERIAL and METHODS}

The study consisted of the patients aged between 0-16 years who visited our hospital's emergency service and/or the neonatology polyclinic, and the adult patients who visited our hospital's obstetrics and gynecology polyclinics and hospitalized in the obstetrics and gynecology service between October 1, 2012 and December 31, 2012. The patients were divided into 3 groups: Group 1, 0-1 year-old babies;
Group 2, female patients older than 16 years, and Group 3 , 1-16 year-old patients. The patients or their parents were informed and their written permission was obtained prior to the measurement of the body temperature. The body temperature of all patients was measured by NCIT (ThermoFlash® LX-26, MSFT V.4) at the right and left temporal regions (maximum of $10 \mathrm{~cm}$ distance between device and skin), and the digital thermometer through the axillary region. Moreover, the body temperature of all newborn babies and infants was measured by digital thermometer through rectal route, of the children by tympanic thermometer (ThermoScan ${ }^{\circledR}$ IRT 4520, Braun), and of the adults by digital thermometer through oral route. Time taken to measure the temperature was 3 minutes for axillary, 2 minutes for rectal, and 2 minutes for oral (approximately 1-3 minutes with digital thermometer), 3 seconds for tympanic, and 1 second for each temporal measurements. All measurements elapsed approximately 5-6 minutes. Only one reading was obtained for each method in each group, except for infrared method which required bilateral readings in order to compare the temperature of both temporal sides.

Among the 0-2 year-old children with body temperature of $\geq 38.0^{\circ} \mathrm{C}$, intermittent rectal and temporal temperature measurements were taken until the body temperature returned to normal level. Among patients whose body temperature values changed, the measured temperature values were divided into subgroups as being $36-37^{\circ} \mathrm{C}, 37-38^{\circ} \mathrm{C}$, and $>38^{\circ} \mathrm{C}$ in order to understand if there is a difference between measurement methods at different temperature levels.

The exclusion criteria from the study were as follows:

- For temporal measurement: if the measurement area was dirty (blood, wound etc.) or covered by tape, bandage, hats etc., or the temporal area was exposed to cold or heat (e.g. environmental factors) before the procedure.

- For rectal measurement: If infection, bleeding or fissures was present in the rectal area.

- For oral measurement: If an oral infection was present, or very hot or cold food and drinks were taken before the procedure. 
- For tympanic measurement: If external ear pathologies were present.

"Statistical Package for the Social Sciences" (SPSS version 15.0, Inc. Chicago, Illinois, USA) and Medcalc programs were used to analyze the data. In order to determine the statistically significant difference between groups, paired t-tests was applied, and the mean, standard deviation and range values were also calculated. Bland-Altman curves were used in order to assess the relationship among measurement methods. In order to determine the strength of the correlation, data analysis included Pearson's r coefficients. In similar studies previously done on this subject, a $\mathrm{p}$ value of $<0.001$ was accepted as a significant difference. Therefore, in order to compare our results with other studies, a $\mathrm{p}$ value of $<0.001$ was accepted as statistically significant.

\section{RESULTS}

The study consisted of a total of 927 patients. In the first group, there were 412 cases (208 male, 204 female) in which 250 of them were newborn babies. The second group consisted of 236 female cases. The third group included 279 cases (150 male, 129 fema-

Table 1. Distribution of the cases according to age groups.

\begin{tabular}{lcccc}
\hline & & \multicolumn{3}{c}{ Age (year) } \\
\cline { 3 - 5 } Group & $\begin{array}{c}\text { Number of the } \\
\text { patients (n) }\end{array}$ & Mean SD & Minimum & Maximum \\
\hline 1 & 412 & $0.13 \pm 0.18$ & 0.01 & 0.90 \\
2 & 236 & $35.85 \pm 12.72$ & 17.00 & 82.00 \\
3 & 279 & $5.14 \pm 4.14$ & 1 & 16.00 \\
Total & 927 & $10.73 \pm 16.32$ & 0.01 & 82.00 \\
\hline
\end{tabular}

SD: Standard deviation. le). Distribution of the cases according to age groups is shown in Table 1.

We did not find any difference between the right and left temporal measurements for all cases including newborn babies ( $>00.05)$. Body temperature measurement results for all cases at different regions which were obtained by different methods are given in Table 2. When body temperature measurement results at different regions which were obtained by different methods were compared, it was determined that;

- In Group 1; the mean temporal temperature was similar to that of rectal temperature $(p>0.05)$. Mean temporal temperature was $0.6^{\circ} \mathrm{C}$ higher than axillary temperature $(\mathrm{p}<0.001)$.

- In Group 2, the mean temporal temperature was $0.5^{\circ} \mathrm{C}$ higher than axillary $(\mathrm{p}<0.001)$ and $0.3^{\circ} \mathrm{C}$ higher than oral temperature $(\mathrm{p}<0.001)$.

- In Group 3, the mean temporal temperature was similar to that of rectal temperature $(\mathrm{p}>0.05)$. It was $0.5^{\circ} \mathrm{C}$ higher than axillary $(\mathrm{p}<0.001)$, and $0.1^{\circ} \mathrm{C}$ higher than tympanic temperature $(\mathrm{p}<0.001)$.

There was a moderate positive correlation between mean temporal temperature and rectal temperatures $(\mathrm{p}<0.001, \mathrm{r}=0.57)$. The average difference between the meantemporal and rectaltemperatures was $-0.03 \pm 0.46^{\circ} \mathrm{C}$ (95\% CI: -0.92-0.87) (Figure 1A). The average difference between the mean temporal and axillary temperatures was $0.59 \pm 0.50^{\circ} \mathrm{C}$ (95\% CI: -0.37-1.55) (Figure 1B). The average difference between the mean temporal and tympanic temperatures was $0.14 \pm 0.58^{\circ} \mathrm{C}(95 \%$ CI: -1.03-1.31) (Figure 1C). The Bland-Altman results showed that most of the data points were tightly clustered around the zero line of the difference between the two temperature readings.

Table 2. Temperature measurement results from the different parts of the body.

\begin{tabular}{lccccc}
\hline Cases & $\begin{array}{c}\text { Temporal } \\
\text { temperature } \\
(\text { Mean } \pm \text { SD) }\end{array}$ & $\begin{array}{c}\text { Rectal } \\
\text { temperature } \\
(\text { Mean } \pm \text { SD) }\end{array}$ & $\begin{array}{c}\text { Axillary } \\
\text { temperature } \\
(\text { Mean } \pm \text { SD) }\end{array}$ & $\begin{array}{c}\text { Oral } \\
\text { temperature } \\
(\text { Mean } \pm \text { SD) }\end{array}$ & $\begin{array}{c}\text { Tympanic } \\
\text { temperature } \\
(\mathbf{M e a n} \pm \text { SD) }\end{array}$ \\
\hline Group 1 $(\mathrm{n}=412)$ & $37.0 \pm 0.4$ & $37.0 \pm 0.4$ & $36.4 \pm 0.5$ & - \\
Group 2 $(\mathrm{n}=236)$ & $36.7 \pm 0.2$ & - & $36.1 \pm 0.3$ & $36.4 \pm 0.5$ & - \\
Group 3 $(\mathrm{n}=279)$ & $37.5 \pm 0.7$ & $37.5 \pm 0.9$ & $37.0 \pm 0.9$ & $36.4 \pm 0.5$ & $37.4 \pm 0.9$ \\
Total $(\mathrm{n}=927)$ & $37.1 \pm 0.6$ & $37.1 \pm 0.5$ & $36.5 \pm 0.7$ & $37.4 \pm 0.9$ \\
\hline
\end{tabular}

SD: Standard deviation. 

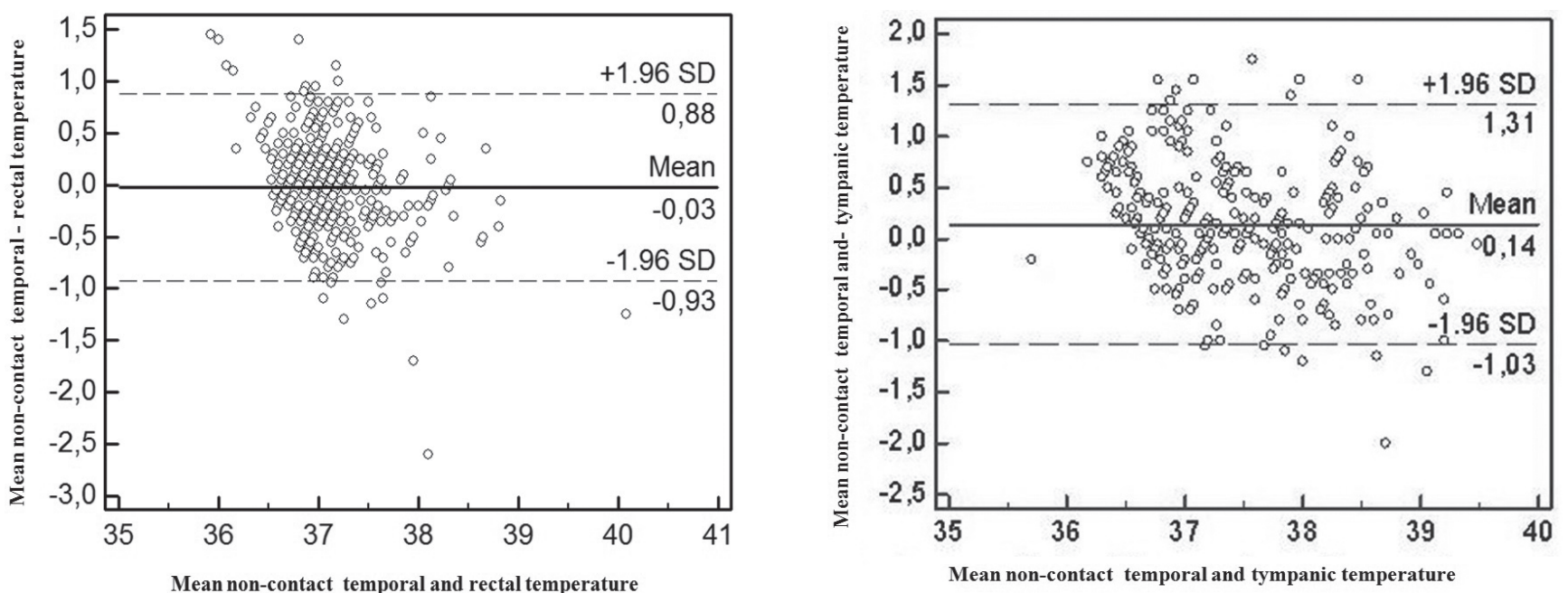

A

C
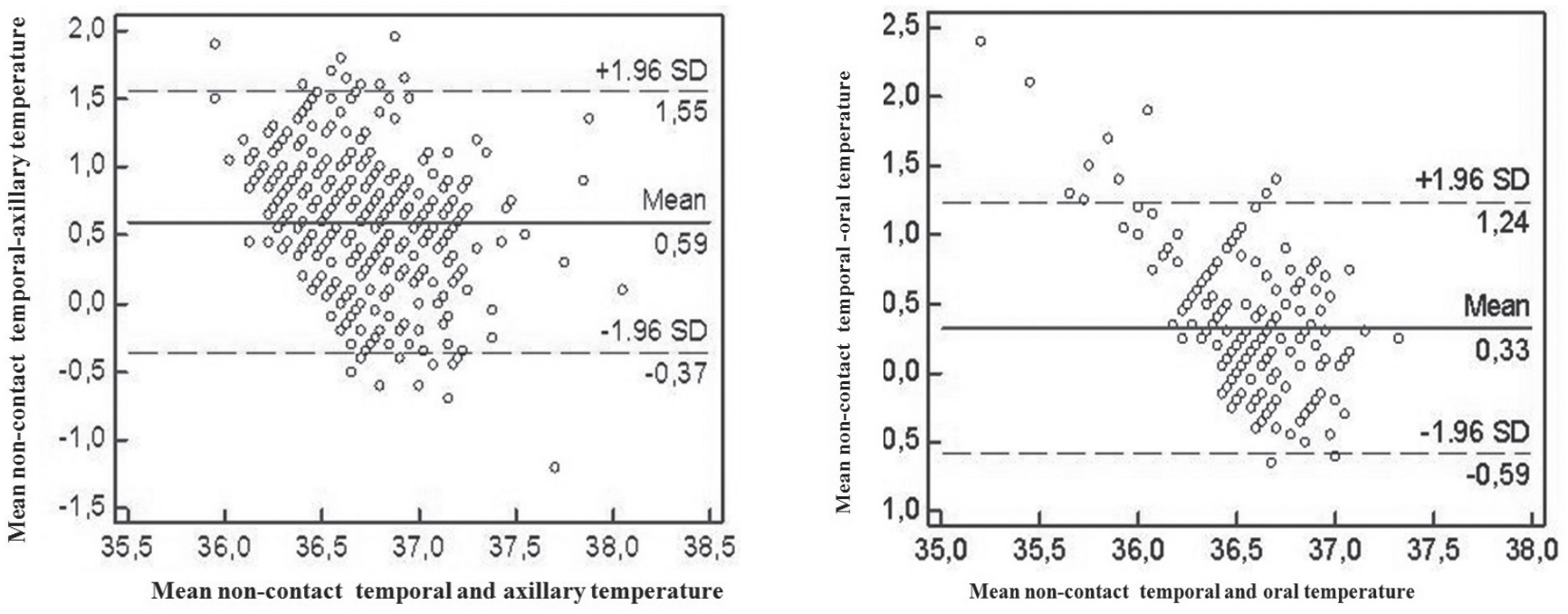

B

D

Figure 1. Plot of the difference between, A) infrared and rectal temperature readings against their mean; B) infrared and axillary temperature readings against their mean; C) infrared and tympanic temperature readings against their mean; D) infrared and oral temperature readings against their mean

Table 3. Difference between the temporal and rectal temperature values at different body temperature levels.

\begin{tabular}{|c|c|c|c|c|c|c|}
\hline \multirow[b]{2}{*}{ Temperature level $\left({ }^{\circ} \mathrm{C}\right)$} & \multicolumn{2}{|c|}{$\begin{array}{c}\text { Right temporal } \\
\text { temperature \& Rectal } \\
\text { temperature }\end{array}$} & \multicolumn{2}{|c|}{$\begin{array}{c}\text { Left temporal } \\
\text { temperature \& Rectal } \\
\text { temperature }\end{array}$} & \multicolumn{2}{|c|}{$\begin{array}{c}\text { Mean temporal } \\
\text { temperature \& Rectal } \\
\text { temperature }\end{array}$} \\
\hline & $\mathbf{n}$ & Difference & $\mathbf{n}$ & Difference & $\mathbf{n}$ & Difference \\
\hline $36-37$ & 114 & -0.1 & 100 & -0.1 & 109 & -0.1 \\
\hline $37-38$ & 150 & -0.1 & 172 & 0.0 & 158 & 0.0 \\
\hline Above 38 & 16 & 0.1 & 16 & 0.2 & 16 & 0.2 \\
\hline Total & 280 & -0.1 & 288 & -0.1 & 283 & -0.1 \\
\hline
\end{tabular}


The difference between the temporal and rectal temperatures at the different body temperature levels are shown in Table 3. If the rectal temperature of $\geq 38^{\circ} \mathrm{C}$ has been taken as a reference value for fever; the sensitivity, specificity, positive and negative predictive values for average temporal temperature were found as $48.5,99.5,88.9$, and $96.3 \%$, respectively.

\section{DISCUSSION}

Body temperature is one of the most commonly used parameters in healthcare. For this measurement , reliable equipment must be used ${ }^{(8)}$. The most accurate method that shows the body temperature is the measurement made via temperature sensors placed in the central venous or arterial (ideally in the pulmonary arteries) catheters ${ }^{(9)}$. The body temperature measured by this method is called as "the central (core) temperature". This method is highly invasive and can be used only in critically ill patients and during interventional procedures. The highest body temperature is measured at rectum and it is approximately $0.2^{\circ} \mathrm{C}$ higher than blood temperature measured from the pulmonary artery. Currently, among the methods used in practice, the rectal temperature measurement is the one that gives the closest temperature value to the central temperature ${ }^{(9-11)}$. In the present study, it was determined that the results of body temperature measurement by NCIT were similar with the rectal temperature measurement results in 0-2 yearold group. Temporal temperature measurement results were positively correlated at moderate level with the rectal temperature in this group. In our study, when we considered $38^{\circ} \mathrm{C}$ as rectal temperature cut-off for fever, the NCIT measurements showed low sensitivity. This method underestimated the body temperature if higher body temperature was present and yielded relatively lower results in the settings of higher rectal temperature $\left(\geq 38^{\circ} \mathrm{C}\right)$. The nearest measurement to rectal temperature was obtained by NCIT, but, we think that this method is not reliable and not ideal for detecting febrile patients. In a study by Allagaert et al. ${ }^{(12)}$ who compared the infrared skin temperature measurement with rectal measurement in order to reflect core temperature, it was reported that temperature measurements by NCITs had been underperformed when compared with rectal measurement. Likewise, underperformance of our infrared skin scan results to detect fever also confirms previous studies ${ }^{(13,14)}$.

There are very few studies about the effectiveness and reliability of NCITs. In a study by Fortuna et al. (15) who compared the NCIT with electronic rectal thermometers, a strong correlation with rectal temperatures was reported $(\mathrm{r}=0.952, \mathrm{p}<0.001)$. This study recruited 434 children from emergency room or inpatient settings and recorded three consecutive temperature readings with each thermometer. It had been reported that NCIT detected fever (rectal temperature of $\geq 38^{\circ} \mathrm{C}$ ) with the sensitivity and specificity of $97 \%$.

In a study by Uslu et al. ${ }^{(16)}$ conducted on 663 infants in a neonatal intensive care unit (NICU), the body temperature measurement results by the NCIT from the forehead was found $0.5^{\circ} \mathrm{C}$ higher than traditional mercury glass thermometer measurements from the axillary region. However, in other study, Kemp et al. ${ }^{(17)}$ concluded that there was a good correlation between these two measurement methods in newborns. In other study, Can et al. ${ }^{(18)}$ reported that NCITs gave higher temperature results than mercury and digital thermometer results in newborn babies staying in NICU. Similarly, in our study NCITs gave higher temperature results than digital thermometer results at axillary region in the newborn group. Therefore, we suggest that these thermometers are not effective and not reliable in assessing body temperature under 1 year old babies, especially in infants staying in NICU.

In a study by $\mathrm{Ng}$ et al. ${ }^{\left({ }^{6}\right)}$ which included 502 patients, a good correlation was found between the tympanic and NCIT measurements. Moreover, they reported that these devices are capable to detect febrile patients accurately. In addition, they stated that it was effective and reliable during the community surveys which were done in the areas where epidemic infections such as severe acute respiratory syndrome and avian influenza were frequently seen. However, in another study by Hausfater et al. ${ }^{(19)}$ which included 2026 patients aged 6-103 years (mean: 46 \pm 19 years) in an emergency department, it was reported 
that NCITs are not reliable enough to detect febrile patients and correlation between NCIT and tympanic measurements was poor. They did not recommend the use of NCIT for the purpose of community surveys. Likewise, our study gave higher temperature measurement results with NCITs than tympanic thermometer.

In conclusion, all noninvasive techniques underperformed when compared to rectal measurement. The NCITs underestimated higher temperatures when compared to rectal measurements. Non-contact infrared thermometer performs less well than expected compared to rectal measurement and other noninvasive techniques. We think that NCIT measurement seems to be the second best, but not yet ideal for detecting febrile patients. Further studies are needed regarding the effectiveness and reliability of this method in order to start the routine use of this thermometer.

\section{REFERENCES}

1. Asher C, Northington L. Position statement for measurement of temperature/fever in children. $J$ Pediatr Nurs 2008;23:234-6.

https://doi.org/10.1016/j.pedn.2008.03.005

2. World Health Organization. Thermal protection of the newborn: a practical guide. WHO/RHT/MSM/97.2; 1997.

3. Rosenthal HM, Leslie A. Measuring temperature of NICU patients-A comparison of three devices. J Neonatal Nurs 2006;12:125-9.

https://doi.org/10.1016/j.jnn.2006.05.007

4. Martin SA, Kline AM. Can there be a standard for temperature measurement in the pediatric intensive care unit? $A A C N$ Clin Issues 2004;15:254-66. https://doi.org/10.1097/00044067-200404000-00011

5. Craig JV, Lancaster GA, Williamson PR, Smyth RL. Temperature measured at the axilla compared with rectum in children and young people: systematic review. BMJ 2000;320:1174-8. https://doi.org/10.1136/bmj.320.7243.1174

6. Ng EY, Kaw GJ, Chang WM. Analysis of IR thermal imager for mass blind fever screening. Microvasc Res 2004;68:104-9.

https://doi.org/10.1016/j.mvr.2004.05.003
7. Wang K, Gill P, Wolstenholme J, Price CP, Heneghan C, Thompson M, et al. Non-contact infrared thermometers for measuring temperature in children: primary care diagnostic technology update. Br J Gen Pract 2014;64:e681-3. https://doi.org/10.3399/bjgp14X682045

8. Geijer H, Udumyan R, Lohse $\mathrm{G}$, Nilsagård Y. Temperature measurements with a temporal scanner: systematic review and meta-analysis. BMJ Open 2016;6:e009509. https://doi.org/10.1136/bmjopen-2015-009509

9. El-Radhi AS, Barry W. Thermometry in paediatric practice. Arch Dis Child 2006;91:351-6. https://doi.org/10.1136/adc.2005.088831

10. Lorin MI. Measurement of body temperature. Semin Pediatr Infect Dis 1993;4:4-8.

11. Farnell S, Maxwell L, Tan S, Rhodes A, Philips B. Temperature measurement: comparison of non-invasive methods used in adult critical care. J Clin Nurs 2005;14:632-9. https://doi.org/10.1111/j.1365-2702.2004.00916.x

12. Allegaert K, Casteels K, van Gorp I, Bogaert G. Tympanic, infrared skin, and temporal artery scan thermometers compared with rectal measurement in children: a real-life assessment. Curr Ther Res Clin Exp 2014;76:34-8. https://doi.org/10.1016/j.curtheres.2013.11.005

13. Paes BF, Vermeulen K, Brohet RM, van der Ploeg T, de Winter JP. Accuracy of tympanic and infrared skin thermometers in children. Arch Dis Child 2010;95:974-8. https://doi.org/10.1136/adc.2010.185801

14. Podolsky S, Spandorfer P, Cohen NJ, Fishbein DB. Mass screening for fever in children: a comparison of 3 infrared thermal detection systems. Pediatr Emerg Care 2013;29:30513. https://doi.org/10.1097/PEC.0b013e3182854465

15. Fortuna EL, Carney MM, Macy M, Stanley RM, Younger JG, Bradin SA. Accuracy of non-contact infrared thermometry versus rectal thermometry in young children evaluated in the emergency department for fever. $J$ Emerg Nurs 2010;36:101-4. https://doi.org/10.1016/j.jen.2009.07.017

16. Uslu S, Ozdemir H, Bulbul A, Comert S, Bolat F, Can E, et al. A comparison of different methods of temperature measurements in sick newborns. J Trop Pediatr 2011;57:418-23. https://doi.org/10.1093/tropej/fmq120

17. Kemp C. Infrared skin thermometer good alternative for newborns. AAP News 2008;29:2.

18. Can E, Bulbul A, Uslu S, Nuhoğlu A. Comparison of noncontact infrared forehead thermometer to standard temperature measurement in neonatal intensive care unit patients. Turk Arch Ped 2010;45:257-63. https://doi.org/10.4274/tpa.45.257

19. Hausfater P, Zhao Y, Defrenne S, Bonnet P, Riou B. Cutaneous infrared thermometry for detecting febrile patients. Emerg Infect Dis 2008;14:1255-8. https://doi.org/10.3201/eid1408.080059 